\title{
Residual nitrogen effects on soil, forage, and steer gain
}

\author{
WILLIAM A. BERG AND PHILLIP L. SIMS
}

Authors are soil scientist and rangeland scientist, respectively, at the USDA-ARS Southern Plains Range Research Station, 2000 18th Street, Woodward, Okla. 73801.

\section{Abstract}

Nitrogen fertilization is a common practice on introduced grass pastures established on marginal farmland in the Southern Great Plains. The efficiency of $\mathbf{N}$ fertilizer use on pastures and concern about nitrate movement into substrata prompted this study of residual $\mathbf{N}$ effects following fertilization. The study was conducted on Old World bluestem (Bothriochloa ischaemum L.) pastures on Pratt soil (sandy, mixed thermic Psammentic Haplustalfs) in western Oklahoma where the 57-year average annual precipitation is $566 \mathrm{~mm} \mathrm{yr}^{-1}$. Herbage production and steer gains were quantified over 3 summer grazing seasons on paddocks fertilized annually with $0,34,68$, or $102 \mathrm{~kg} \mathrm{~N} \mathrm{ha}^{-1} \mathrm{yr}^{-1}$ during the preceding 5 years. Peak standing ungrazed herbage yields were 2 - to 4 -fold greater in paddocks fertilized the preceding 5 years and were linearly related to the total $\mathrm{N}$ applied the previous 5 years. Steer weight gain responded linearly to $N$ with an average of $0.63 \mathrm{~kg}$ gain over 3 years per $\mathrm{kg} \mathrm{N}$ applied over the preceding 5 years. No differences $(P>0.05)$ in soil nitrate concentrations to a depth of $2.8 \mathrm{~m}$ were measured among the $\mathrm{N}$ rate treatments. Overall, substantial effects of residual $N$ were measured in both herbage mass and steer weight gain for 3 years following 5 years of $N$ fertilization.

Key Words: Southern Plains, marginal farmland, grass fertilization, Old World bluestem, Bothriochloa ischaemum, forage quality

Nitrogen $(\mathrm{N})$ fertilization of introduced grass pastures is a common practice in western Oklahoma and adjacent areas in Texas (Dahl and Cotter 1984, Berg and Sims 1995). These pastures are usually established on marginal farmland that are deficient in plant-available $\mathrm{N}$ as a result of up to 100 years of cultivation and subsequent erosion (Haas et al. 1957). Management of $\mathrm{N}$ fertilized pastures requires a balance among production, profit, and environmental quality (Bock and Hergert 1991).

A single application of $68 \mathrm{~kg} \mathrm{~N} \mathrm{ha}^{-1} \mathrm{yr}^{-1}$ in April to WW Spar Old World bluestem (Bothriochloa ischaemum L.) pastures in western Oklahoma generally resulted in maximum forage mass and steer weight gain (Berg and Sims 1995). However, fertilizer

The authors thank the Agricultural Research Technicians and other support personnel at the Southern Plains Experimental Range, and Tom Popham for statistical analysis, and Sherry Dewald for manuscript processing.

All programs and services of the U. S. Department of Agriculture are offered on a nondiscriminatory basis without regard to race, color, national origin, religion, sex, age, marital status, or handicap.

Names are necessary to report factually on available data; however, the USDA neither guarantees nor warrants the standard of the product, and the use of the name by USDA implies no approval of the product to the exclusion of others that may also be suitable.

Manuscript accepted 3 July 1999.

\section{Resumen}

La fertilización nitrogenada es una práctica común en las praderas de pastos introducidos establecidas en las tierras agrícolas marginales de las Grandes Planicies del Sudeste. La eficiencia del uso de fertilizante nitrogenado en praderas y la preocupación acerca del movimiento de los nitratos hacia el substrato motivo la realización de este estudio de los efectos del nitrógeno residual seguido de la fertilización. Este estudio se condujo en praderas de "Old World Bluestem" (Bothriocloa aschaemum L.) en suelo Pratt (sandy, mixed thermic, Psemmentic Haplustalfs) localizadas en el oeste de Oklahoma, en donde el promedio de precipitación

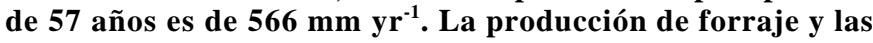
ganancias de los novillos se cuantificaron en 3 estaciones de apacentamiento en verano en potreros que habían fertilizado

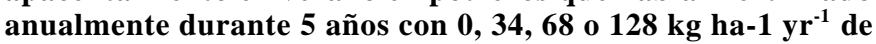
nitrógeno. Los rendimientos máximos de producción del forraje sin apacentar fue de 2 a 4 veces mayor en los potreros fertilizados durante los 5 años previos y estuvieron linealmente relacionados con la cantidad total de nitrógeno aplicado en los 5 años. Las ganancias de peso de los novillos respondieron linealmente a la aplicación de nitrógeno con un promedio en 3 años $0.63 \mathrm{~kg}$ de ganancia por kg de nitrógeno aplicado en los 5 años anteriores. No se encontraron diferencias $(P>0.05)$ entre tratamientos de nitrógeno con respecto en las concentraciones de nitratos medidas hasta una profundidad de $2.8 \mathrm{~m}$. En general, se midieron efectos substanciales del nitrógeno residual tanto en la producción de forraje como las ganancias de peso de los novillos durante 3 los tres años posteriores a 5 años de fertilización nitrogenada.

$\mathrm{N}$-use efficiency in steer weight gain was greater for a lower $\mathrm{N}$ application rate of $34 \mathrm{~kg} \mathrm{~N} \mathrm{ha}^{-1} \mathrm{yr}^{-1}$. Fertilizer $\mathrm{N}$-use efficiency averaged $3.3 \mathrm{~kg}$ steer weight gain per $\mathrm{kg} \mathrm{N}$ applied with the first $34 \mathrm{~kg} \mathrm{~N} \mathrm{ha}^{-1} \mathrm{yr}^{-1}$ increment, $1.0 \mathrm{~kg}$ for the second $34 \mathrm{~kg} \mathrm{~N}^{-1} \mathrm{yr}^{-}$ 1 increment (total of $68 \mathrm{~kg} \mathrm{~N} \mathrm{ha}^{-1} \mathrm{yr}^{-1}$ ) and was negligible for the third $34 \mathrm{~kg} \mathrm{~N} \mathrm{ha}^{-1} \mathrm{yr}^{-1}$ increment (total of $102 \mathrm{~kg} \mathrm{~N} \mathrm{ha}^{-1} \mathrm{yr}^{-1}$ ).

This study is a continuation of an earlier $\mathrm{N}$ rate study reported by Berg and Sims (1995). The objectives of the present study were to determine the residual $\mathrm{N}$ effects after 5 years of pasture fertilization on: 1) concentrations of nitrate, ammonium, total $\mathrm{N}$ and organic $\mathrm{C}$ in the soil; and 2) herbage mass, forage nutritive value, and steer weight gain in the ensuing 3 years without fertilization.

\section{Materials and Methods}

This study was conducted on the Southern Plains Experimental Range near Fort Supply $\left(99^{\circ} 23^{\prime} \mathrm{W}, 36^{\circ} 27^{\prime} \mathrm{N}\right)$ in western Oklahoma. Soils are predominately a deep loamy sand (Pratt series-sandy, 
mixed, thermic Psammentic Haplustalfs). Prior to cultivation, the land supported a sand sagebrush (Artemisia filifolia Torr.)mixed grass prairie with sand bluestem (Andropogon hallii Hack.), sand dropseed (Sporobolus cryptandrus (Torr.) Gray), blue grama (Bouteloua gracilis (H.B.K.)Lag.), switchgrass (Panicum virgatum L.), and little bluestem (Schizachyrium scoparium (Michx.) Nash) as dominant grasses (Berg 1994).

The study area was farmed for about 40 years before 'WW-Spar' Old World bluestem was established in the early 1980's. The bluestem pasture was fertilized with $68 \mathrm{~kg} \mathrm{~N} \mathrm{ha}^{-1} \mathrm{yr}^{-1}$ and grazed in 1986 and 1987. In 1988 the pasture was divided into 16 paddocks and ammonium nitrate treatments of $0,34,68$, and $102 \mathrm{~kg} \mathrm{~N}^{-1}$ $\mathrm{yr}^{-1}$ were broadcast applied in April of each year in a randomized complete block design with 4 replications. The $\mathrm{N}$ treatments were repeated for 5 years between 1988 and 1992 (Berg and Sims 1995). Incremental $\mathrm{N}$ rates were obtained by repeat applications of fertilizer, on the same day, with a drop spreader calibrated for the $34 \mathrm{~kg} \mathrm{~N} \mathrm{ha}^{-1} \mathrm{yr}^{-1}$ rate. Thus, the total amount of $\mathrm{N}$ applied over the 5-year period was $0,170,340$, and $510 \mathrm{~kg} \mathrm{~N}^{-1}$ for the respective annual $\mathrm{N}$ treatments. Paddocks were 1.2 ha for the control (no N) and 0.8 ha for each $\mathrm{N}$-fertilized treatment.

Paddocks were grazed 4 of the 5 years $\mathrm{N}$ fertilizer was applied (Berg and Sims 1995). A low temperature of -20 ${ }^{\circ} \mathrm{C}$ on $22 \mathrm{D}$ e c e m b e r 1989, following a dry fall (4 $\mathrm{mm}$ precipitation October through December 1989) resulted in extensive winterkill of WW-Spar Old World bluestem. To allow forage recovery, the bluestem pastures were not grazed during the 1990 growing season.

Soil sampling was designed to test differences among N-rate treatments following 5 years of $\mathrm{N}$ fertilization. Samples were taken in the spring of 1988 prior to $\mathrm{N}$ fertilization and again in the spring of 1993, approximately 1 year following the last application of $\mathrm{N}$ fertilizer. Two groups of soil samples were taken; the first was to characterize fertility in the surface $15 \mathrm{~cm}$ of soil, the second was to determine nitrate $\left(\mathrm{NO}_{3}\right)$ and ammonium $\left(\mathrm{NH}_{4}\right)$ movement and accumulation to a depth of $2.8 \mathrm{~m}$. Prior to soil sampling in 1988 and 1993, forage aftermath was burned in March. For the soil fertility sampling, because of soil heterogeneity within paddocks caused by topography and erosion, 3 representative $6 \times 10 \mathrm{~m}$ areas within each paddock were permanently marked and sampled in 1988 and resampled in 1993 . Twentyeight random $2-\mathrm{cm}$ diameter cores were taken to a depth of $15 \mathrm{~cm}$ in each $6 \times 10 \mathrm{~m}$ sampling area, composited by $5 \mathrm{~cm}$ increments, and air dried. Soil samples were passed through a $2 \mathrm{~mm}$ sieve to remove roots and foreign material prior to storage or analysis. Thus, 9 soil samples, composited from 28 subsamples, were collected in 1988 and again in 1993 for analyses from each paddock ( 3 areas x 3 depths). Data were averaged from the 3 areas (subsamples) per paddock for later statistical analyses. Nitrate was determined by $1 \mathrm{M}$ $\mathrm{KCl}$ extraction and $\mathrm{Cd}$ reduction (Gelderman and Fixen 1988), extractable ammonium by $1 \mathrm{M} \mathrm{KCl}$ extraction and the indophenol blue method (Keeny and Nelson 1982), total $\mathrm{N}$ by a Kjeldahl procedure (Bremner and Breitenbeck 1983), and organic $\mathrm{C}$ by the Mebius method (Nelson and Sommers 1982). Soil samples were air dried and stored in a cool, dry area and all analyses made in 1994.

Nitrate and ammonium concentrations to a depth of $2.8 \mathrm{~m}$ were determined in 4$\mathrm{cm}$ diameter soil cores taken at increments of 0-0.4, 0.4-1.2, 1.2-2.0., and 2.0-2.8 m. One core was taken per paddock in 1988 , the location marked, and another core taken in 1993 within $0.5 \mathrm{~m}$ of the original location. Samples were air dried and nitrate and ammonium determined by methods given above.

Precipitation measured at the Southern Plains Experimental Range headquarters, about $1.5 \mathrm{~km}$ from the research site, was $459 \mathrm{~mm}$ in 1993, $480 \mathrm{~mm}$ in 1994, and $457 \mathrm{~mm}$ in 1995 (Table 1). The 57 year mean is $566 \mathrm{~mm} \mathrm{yr}^{-1}$. January through June precipitation was $257 \mathrm{~mm}$ in 1993, $201 \mathrm{~mm}$ in 1994, and $338 \mathrm{~mm}$ in 1995; the
57 year January through June precipitation mean is $290 \mathrm{~mm}$. Average annual precipitation for the previous 5 years, beginning in 1988 was 503, 679, 560, 409, and 503 $\mathrm{mm}$, respectively.

Peak standing herbage mass was harvested within five, $1.25 \times 4 \mathrm{~m}$ exclosures within each paddock on 15 July 1993, 28 June 1994, and 1 July 1995 . The exclosures were moved annually. Herbage was cut at a $7-\mathrm{cm}$ height with a Hegge sickle bar plot harvester on $1.25 \mathrm{X} 4 \mathrm{~m}$ areas within each exclosure, collected as one sample, and weighed. Herbage mass in each paddock was also cut at a $7-\mathrm{cm}$ height with a Hegge sickle bar plot harvester by randomly sampling five, $1.25 \mathrm{x}$ $4 \mathrm{~m}$ areas within each paddock at the time steers were placed in the paddocks, 3 weeks later, and when the steers were moved. Herbage subsamples, of approximately $300 \mathrm{~g}$ size, were collected and dried at $57^{\circ} \mathrm{C}$ to determine dry matter content. These dried samples were ground to pass a 1-mm screen and analyzed for $\mathrm{N}$ (Bremner and Breitenbeck 1983) and in vitro dry matter digestibility (Tilley and Terry 1963 as modified by White et al. 1981). Nitrogen concentration was multiplied by 6.25 to estimate crude protein.

In this monoculture pasture, herbage mass sampled to a stubble height of $7 \mathrm{~cm}$ was considered to approximate the available forage mass for the grazing animal. Thus, herbage allowance was calculated as the average herbage mass in each paddock within each sampling interval divided by the number of steers and steer weight $(\mathrm{kg})$ in the paddock over that period.

Yearling steers were placed in the paddocks in June when grass height was visually estimated to be between 15 and 20 $\mathrm{cm}$. Steers were grazing similar Old World bluestem forage prior to the beginning of this summer grazing study. Steers grazed Old World bluestem in this study at or near peak nutritive value and when grass growth rates were generally high until mid July or early August. Steers, crosses of Hereford or Angus with Simmental, Limousin, or Brahman, were implanted with $200 \mathrm{mg}$ progesterone and $20 \mathrm{mg}$

Table 1. Monthly precipitation $(\mathrm{mm})$ during the years of the study (1993-1995) compared to the 57-year mean at the Southern Plains Experimental Range, 1940-1989, Ft. Supply, Okla.

\begin{tabular}{|c|c|c|c|c|c|c|c|c|c|c|c|c|c|}
\hline YearJan. & Feb. & Mar. & Apr. & May & Jun. & Jul. & Aug. & Sep. & Oct. & Nov. & Dec. & Total & \\
\hline & $\cdots$ & $\cdots$ & $\cdots$ & - & -- & -- & )-- & --- & 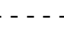 & -- & - & -1 & \\
\hline 1993 & 36 & 36 & 40 & 56 & 78 & 11 & 59 & 86 & 22 & 10 & 17 & 10 & 459 \\
\hline 1994 & 12 & 17 & 28 & 74 & 55 & 15 & 78 & 48 & 28 & 64 & 26 & 34 & 480 \\
\hline 1995 & 15 & 4 & 103 & 28 & 115 & 73 & 53 & 13 & 36 & 0 & 1 & 18 & 457 \\
\hline Mean & 21 & 19 & 57 & 53 & 83 & 33 & 63 & 49 & 29 & 25 & 15 & 21 & 465 \\
\hline 56-year & 14 & 24 & 40 & 46 & 90 & 76 & 71 & 64 & 52 & 42 & 28 & 21 & 566 \\
\hline
\end{tabular}


estradiol benzoate in May. Initial weights of the 56 steers used each year averaged $298 \pm 3(\mathrm{SE}) \mathrm{kg}$ in $1993,232 \pm 3 \mathrm{~kg}$ in 1994 , and $257 \pm 3 \mathrm{~kg}$ in 1995 . Steers were weighed on the morning they were placed in the paddocks, and the day after they were removed. All steer weights followed an 18 hour fast without feed or water.

The number of steers used during the first 3 weeks was based on experience from the earlier 5-year $\mathrm{N}$ fertilization study by Berg and Sims (1995) and from previous studies at the Southern Plains Experimental Range (Sims and Dewald 1982). Steer numbers were adjusted slightly for the second grazing interval in an attempt to maintain similar amounts of forage mass per steer in each paddock. Because of variation in herbage growth, the subsequent grazing level was not always precise. Thus, care must be exercised in interpreting average daily weight gain and gain ha-1. Steer weight gain per paddock was the experimental unit used in the statistical analysis (SAS Institute 1985).

Cattle were removed and the pastures allowed to regrow before fall dormancy. Number of continuous grazing days was 35,33 , and 42 days in 1993, 1994, and 1995, respectively. Aftermath was burned in March 1993, but mowed and dropped in place in March of 1994 and 1995.

Residual N fertilizer use efficiency was calculated for each year (1993-95) by subtracting steer weight gain $\mathrm{ha}^{-1} \mathrm{yr}^{-1}$ on the unfertilized paddocks from steer weight gain $\mathrm{ha}^{-1} \mathrm{yr}^{-1}$ on paddocks $\mathrm{N}$ fertilized over the 1988-1992 period and then dividing by the total amount of $\mathrm{N}$ applied over the 1988-1992 period.

For the soil analyses our major interest was 5 years differences (deltas between 1988 and 1993) as affected by $\mathrm{N}$ treatments; therefore, the delta values were used in statistical analyses. Soil sampling design was a randomized complete block with rate of $\mathrm{N}$ as the treatment variable. Observations were made at incremental depths vertically within treatments. The analysis of variance (AOV) model was a randomized complete block with a block effect, $\mathrm{N}$ rate effect and depths analyzed as a repeated factor, which allowed for adjustment for correlation between depths when testing for depths and the depth $\mathrm{x} N$ rate interaction effects. The significance levels for $\mathrm{N}$ rates were determined by $\mathrm{F}$ tests and significance levels for depth and the depth $\mathrm{x} \mathrm{N}$ rate interaction were determined by Kendall's Tau. Analysis of variance was conducted for steer weight gain $\mathrm{ha}^{-1}$ as affected by $\mathrm{N}$ rates over years and for each year; treatment effects were also partitioned into linear, quadratic, cubic, and residual components by year. Peak standing herbage mass for each year (1988-1994) was analyzed using a repeated measure, 2-way AOV with correction for correlation between successive years. The AOV was conducted for average daily steer gain (ADG) and forage nutritive components. Duncan's new multiple range test $(\mathrm{P}<0.05)$ was used to separate treatment effects on steer ADG. Statistical analyses was conducted using SAS Institute (1985) procedures.

\section{Results and Discussion}

\section{Soil $\mathbf{N}$ and $\mathbf{C}$}

In the soil fertility analyses of the surface $15 \mathrm{~cm}$, nitrate was low with no significant change $(\mathrm{P}>0.05)$ following 5 years of pasture fertilization compared to nonfertilization (Table 2). Ammonium concentration increased $(\mathrm{P}<0.01)$ with increased $\mathrm{N}$ application, however, overall ammonium concentrations were lower in 1993 than in 1988. Extractable mineral N (nitrate and ammonium) has been commonly used as a routine soil test for plantavailable $\mathrm{N}$ in cultivated soils (Dahnke and Johnson 1990). However, peak herbage standing mass (Fig. 1) indicated that substantially more $\mathrm{N}$ was available to plants in paddocks receiving higher $\mathrm{N}$ rates in the preceding 5 years. Thus, routine agricultural soil tests for extractable nitrate and ammonium appear to be of little to no value in predicting $\mathrm{N}$ availability to plants in these and similar pastures. An exception to this might be when excessive fertilizer $\mathrm{N}$ is applied. Soil incubation tests (Dahnke and Johnson 1990) however, may be useful for quantifying $\mathrm{N}$ which becomes available from mineralization of organic $\mathrm{N}$ in pastures.

Table 2. Soil nitrate, ammonium, total $\mathrm{N}$, and organic $\mathrm{C}$ concentrations to $15 \mathrm{~cm}$ soil depth before (1988) and after (1993) 5 years of $\mathrm{N}$ fertilization and grazing of an Old World bluestem at the Southern Plains Experiemental Range, Ft. Supply, Okla.

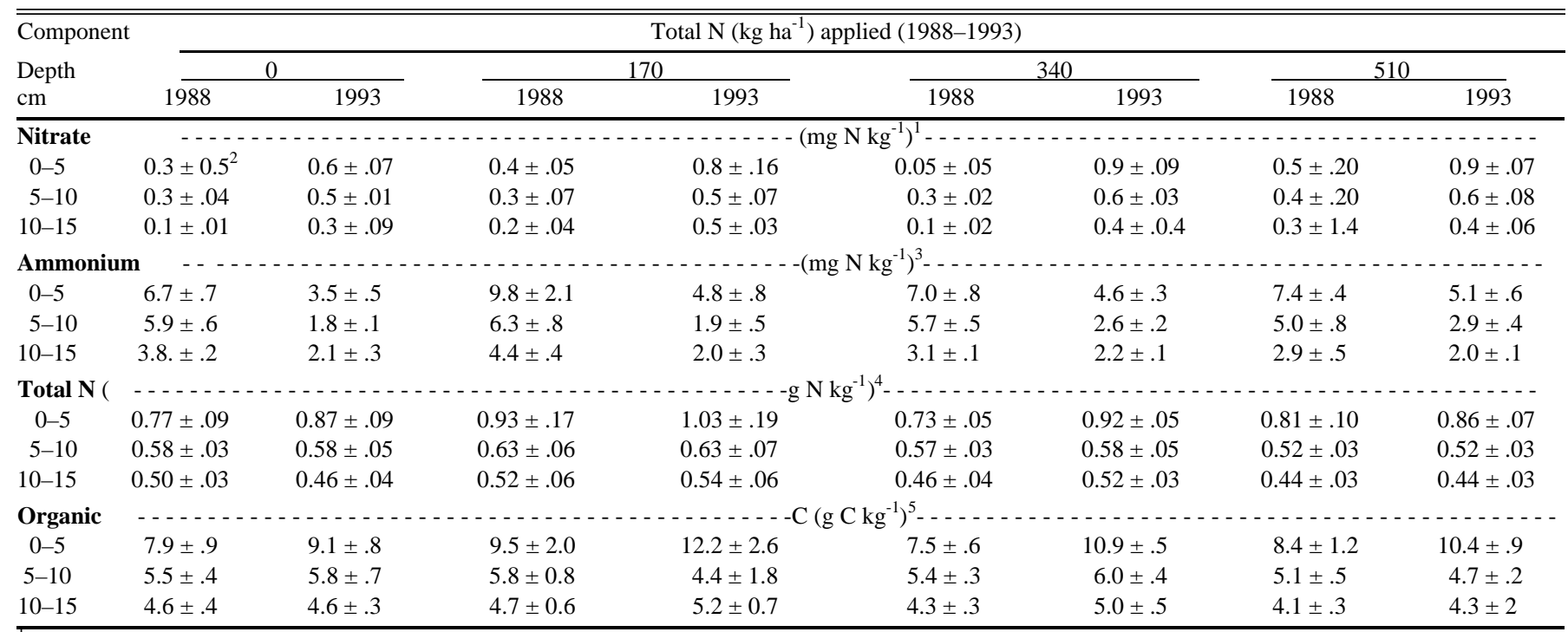

${ }_{\mathrm{P}}^{\mathrm{P}}>\mathrm{F}$ for differences in nitrate levels between years for $\mathrm{N}$ treatments $=0.85$, soil depths $=0.09$, and $\mathrm{N} \mathrm{X}$ soild depths $=0.98$.

${ }^{2}$ Standard error (s.e.), $\mathrm{n}=4$.

${ }^{3} \mathrm{P}>\mathrm{F}$ for differences in ammonium levels between years for $\mathrm{N}$ treatments $=0.01$, soil depths $=0.01$, and for $\mathrm{N} X$ soil depths $=0.87$.

${ }^{4} \mathrm{P}>\mathrm{F}$ for differences in total $\mathrm{N}$ levels between years for $\mathrm{N}$ treatments $=0.13$, soil depths $=0.01$, and for $\mathrm{N} \mathrm{X}$ soil depths $=0.68$. 


\section{Peak standing crop $\left(\mathrm{kg} \mathrm{ha}^{-1}\right)$}

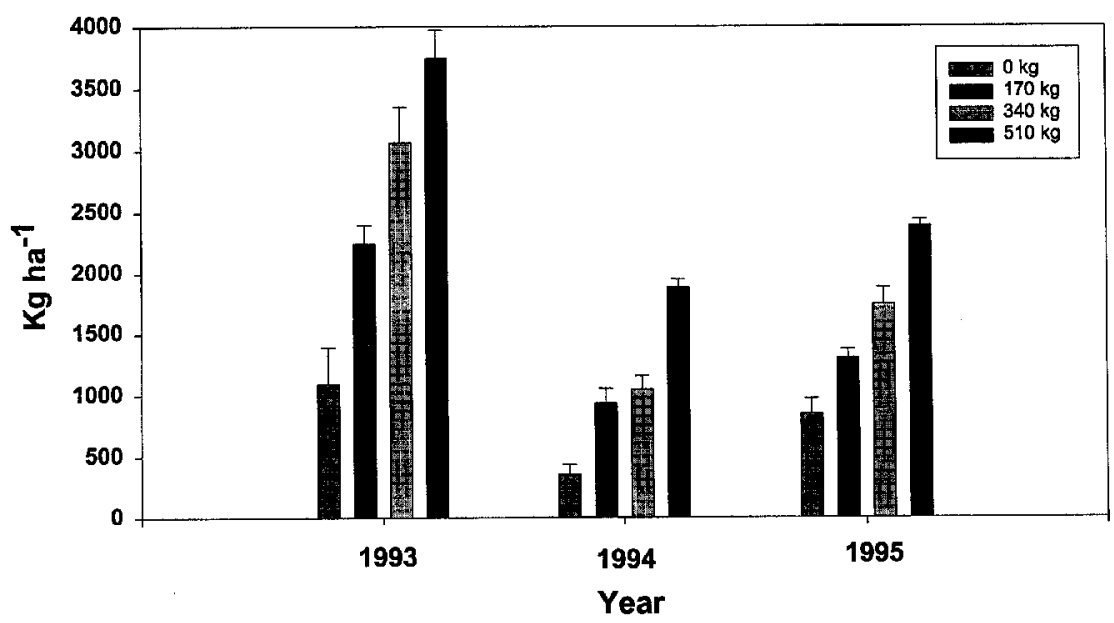

Fig. 1. Peak standing herbage mass $\left(\mathrm{kg} \mathrm{ha}^{-1} \pm\right.$ s.e. $)$ in 1993, 1994, and 1995 in exclosures within paddocks. Paddocks were fertilized with a total of $0,170,340$, and $510 \mathrm{~kg} \mathrm{~N} \mathrm{ha}^{-1}$ during the previous 5 years at the Southern Plains Experimental Range, Ft. Supply, Okla.

Total soil $\mathrm{N}$ and organic $\mathrm{C}$ concentrations increased in the surface $5 \mathrm{~cm}$ in all treatments over the 1988-1993 period. However, our major interest was whether or not there was a greater change in total $\mathrm{N}$ and organic $\mathrm{C}$ in the $\mathrm{N}$-fertilized paddocks than in the unfertilized paddocks. Thus, we calculated the change from 1988 to 1993 in total $\mathrm{N}$ and organic $\mathrm{C}$ for each $\mathrm{N}$ treatment and subjected the data to AOV. No significant change was measurable in total $\mathrm{N}(\mathrm{P}=0.13)$, but organic $\mathrm{C}$ increased $(\mathrm{P}=0.03)$ with increased $\mathrm{N}$ application (Table 2).

The potential for movement of mineral $\mathrm{N}$ into substrata and eventually into groundwater has been a concern with $\mathrm{N}$ fertilization of pastures. There was more $(\mathrm{P}<0.05)$ extractable nitrate in all treatments to a depth of $2.8 \mathrm{~m}$ in 1993 than in
1988 (Table 3). However, most levels of extractable nitrate, about $1 \mathrm{mg} \mathrm{N} \mathrm{kg}^{-1}$ soil ( 1 ppm extractable nitrate $\mathrm{N}$ ), were low. Higher nitrate concentrations were found at depths of 1.2 to $2.8 \mathrm{~m}$ in some soil samples from the higher $\mathrm{N}$ rate treatments; however, this was not consistent among replications and thus $\mathrm{N}$ treatments $\mathrm{X}$ depths interaction was not significant $(\mathrm{P}>$ $0.05)$. We believe that more intensive sampling is needed to quantify nitrate movement than the single adjacent soil cores we took per paddock in 1988 and 1993.

\section{Herbage dynamics}

Peak standing herbage yields from exclosures within paddocks that were $\mathrm{N}$ fertilized the preceding 5 years were 2- to 4-fold greater than yields from exclosures within paddocks that had not been fertilized (Fig. 1). There were significant differences $(P<0.01)$ in peak standing herbage yields between the $\mathrm{N}$ levels and years when residual $\mathrm{N}$ effects were measured. These differences were, however, not independent $(\mathrm{P}<0.05)$ because the relative difference in herbage mass and amount of $\mathrm{N}$ applied during the previous 5 years was not the same in all years, particularly in 1994 (Fig. 1). The increase was linearly related to total $\mathrm{N}$ applied with $\mathrm{r}^{2}$ values of 0.82 in 1993, 0.85 in 1994, and 0.90 in 1995 . This linear relationship indicated that $\mathrm{N}$ was a limiting factor in herbage mass yields on all residual $\mathrm{N}$ treatments each year the residual effect was measured. In contrast, yields of herbage mass during the 5 years that $\mathrm{N}$ was applied was curvilinearly related as increasing $\mathrm{N}$ fertilizer increments produced smaller increases in herbage mass (Berg and Sims 1995). Precipitation during the growing season for 1993, 1994, and 1995 was 185,172 , and $339 \mathrm{~mm}$, respectively (Table 1 ). The dynamics of peak standing herbage is a function of available $\mathrm{N}$ levels in the soil and recent precipitation. The separate effects on these 2 factors cannot be partitioned in this study. However, the relative responses from the $\mathrm{N}$ fertilizer treatments were consistent across all 3 years.

Available herbage mass per $100 \mathrm{~kg}$ steer $^{-1}$ weight averaged $60 \pm 3 \mathrm{~kg}$ across all treatments, grazing periods, and years (Table 4). There were no significant differences in the amounts of herbage mass per $100 \mathrm{~kg} \mathrm{steer}^{-1}$ between treatments within each period. Over the 3 years, herbage allowance averaged $139 \pm 15,170$ $\pm 20,133 \pm 14$, and $172 \pm 16 \mathrm{~kg}$ forage steer $^{-1}$ for the $0,170,340$, and $510 \mathrm{~kg}$ total $\mathrm{N} \mathrm{ha}^{-1}$ applied, respectively. There were

Table 3. Soil nitrate, ammonium concentrations to 2.8 msoil depth before (1988) and after (1993) 5 years of $\mathbf{N}$ fertilization and grazing of an Old World bluestem at the Southern Plains Experimental Range, Ft. Supply, Okla.

\begin{tabular}{|c|c|c|c|c|c|c|c|c|}
\hline \multirow{3}{*}{$\begin{array}{l}\text { Component } \\
\text { Depth } \\
\mathrm{m}\end{array}$} & \multicolumn{8}{|c|}{ Total N (kg ha $\left.{ }^{-1}\right)$ applied (1988-1993) } \\
\hline & \multicolumn{2}{|c|}{0} & \multicolumn{2}{|c|}{170} & \multicolumn{2}{|c|}{340} & \multicolumn{2}{|c|}{510} \\
\hline & 1988 & 1993 & 1988 & 1993 & 1988 & 1993 & 1988 & 1993 \\
\hline Nitrate & \multicolumn{8}{|c|}{ 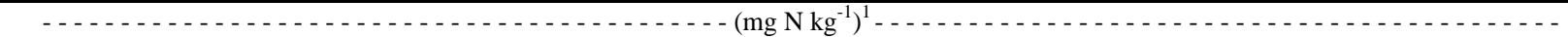 } \\
\hline $0-0.4$ & $0.3 \pm 0.1^{2}$ & $0.7 \pm .0 .1$ & $0.3 \pm 0.1$ & $0.9 \pm 0.1$ & $0.3 \pm 0.1$ & $1.0 \pm 0.2$ & $0.3 \pm 0.1$ & $1.0 \pm 0.1$ \\
\hline $.0 .4-1.2$ & $0.4 \pm 0.1$ & $0.7 \pm 0.1$ & $0.3 \pm .07$ & $05 . \pm .07$ & $0.3 \pm .02$ & $0.6 \pm .03$ & $0.4 \pm .20$ & $0.6 \pm .08$ \\
\hline $1.2-2.0$ & $0.3 \pm 0.1$ & $0.7 \pm 0.1$ & $0.5 \pm 0.2$ & $1.1 \pm 0.4$ & $0.3 \pm 0.1$ & $1.0 \pm 0.4$ & $0.3 \pm 0.1$ & $0.5 \pm 0.4$ \\
\hline $2.0-2.8$ & $0.6 \pm 0.1$ & $0.8 \pm 0.1$ & $0.9 \pm 0.3$ & $1.4 \pm 0.2$ & $0.9 \pm 0.3$ & $2.9 \pm 1.5$ & $0.3 \pm 1.6$ & $3.0 \pm 2.0$ \\
\hline \multicolumn{9}{|l|}{ Ammonium } \\
\hline $0-0.4$ & $5.2 \pm 0.4$ & $2.4 \pm 0.3$ & $4.7 \pm 0.5$ & $2.5 \pm 0.2$ & $5.2 \pm 0.3$ & $2.6 \pm 0.1$ & $5.1 \pm 0.9$ & $2.7 \pm 0.3$ \\
\hline $0.4-1.2$ & $1.9 \pm 0.1$ & $2.0 \pm 0.4$ & $2.3 \pm 0.3$ & $2.0 \pm 0.4$ & $2.0 \pm 0.4$ & $1.5 \pm 0.2$ & $2.3 \pm 0.3$ & $1.8 \pm 0.6$ \\
\hline $1.2-2.0$ & $1.6 \pm 0.1$ & $1.2 \pm 0.2$ & $2.3 \pm 0.6$ & $1.9 \pm 0.3$ & $1.5 \pm 0.3$ & $1.0 \pm 0.2$ & $1.8 \pm 0.5$ & $3.0 \pm 1.2$ \\
\hline $2.0-2.8$ & $1.6 \pm 0.1$ & $1.5 \pm 0.2$ & $2.3 \pm 0.6$ & $2.1 \pm 0.6$ & $1.4 \pm 0.2$ & $1.9 \pm 0.2$ & $1.1 \pm 0.2$ & $.1 .5 \pm 0.2$ \\
\hline
\end{tabular}

${ }^{\mathrm{P}} \mathrm{P}>\mathrm{F}$ for differences in nitrate levels between years for $\mathrm{N}$ treatments $=0.21$, soil depths $=0.25$, and $\mathrm{N} \mathrm{X}$ soild depths $=0.27$.

${ }^{2}$ Standard error (s.e.), $\mathrm{n}=4$.

${ }^{3} \mathrm{P}>\mathrm{F}$ for differences in ammonium levels between years for $\mathrm{N}$ treatments $=0.52$, soil depths $=0.01$, and for $\mathrm{N} \mathrm{X}$ soil depths $=0.31$ 
Table 4. Stocking density and available herbage per $100 \mathrm{~kg}$ yearling $\operatorname{steer}^{-1}(\mathrm{~kg} \pm \mathrm{se})$ for 2 summer grazing periods to determine residual $\mathrm{N}$ effects over 3 years following 5 years of $N$ fertilization with $0,170,340$, and $570 \mathrm{~kg} \mathrm{~N} \mathrm{ha}^{-1}$ at the Southern Plains Experimental Range, Ft. Supply, Okla.

\begin{tabular}{|c|c|c|c|c|c|c|c|c|c|}
\hline \multirow[t]{2}{*}{ Year } & \multirow[t]{2}{*}{ Grazing Interval } & \multicolumn{6}{|c|}{ Total $\mathrm{N}\left(\mathrm{kg} \mathrm{ha}^{-1}\right)$ applied from 1988 to 1992} & \multirow{2}{*}{\multicolumn{2}{|c|}{510}} \\
\hline & & \multicolumn{2}{|c|}{0} & \multicolumn{2}{|c|}{170} & \multicolumn{2}{|c|}{340} & & \\
\hline 1993 & $\begin{array}{l}7 \text { June-29 June } \\
\text { 30 June-12 July }\end{array}$ & $\begin{array}{l}2.5 \\
2.3\end{array}$ & $\begin{array}{l}24 \pm 6 \\
43 \pm 9\end{array}$ & $\begin{array}{l}3.7 \\
3.1\end{array}$ & $\begin{array}{l}45 \pm 14 \\
84 \pm 28\end{array}$ & $\begin{array}{l}4.9 \\
4.3\end{array}$ & $\begin{array}{l}36 \pm 10 \\
54 \pm 14\end{array}$ & $\begin{array}{l}4.9 \\
4.9\end{array}$ & $\begin{array}{l}46 \pm 9 \\
63 \pm 16\end{array}$ \\
\hline 1994 & $\begin{array}{l}8 \text { June-27 June } \\
28 \text { June-11 July }\end{array}$ & $\begin{array}{l}2.5 \\
2.5\end{array}$ & $\begin{array}{l}61 \pm 4 \\
56 \pm 5\end{array}$ & $\begin{array}{l}3.7 \\
3.4\end{array}$ & $\begin{array}{l}79 \pm 11 \\
93 \pm 11\end{array}$ & $\begin{array}{l}4.9 \\
4.9\end{array}$ & $\begin{array}{l}70 \pm 9 \\
74 \pm 11\end{array}$ & $\begin{array}{l}4.9 \\
5.3\end{array}$ & $\begin{array}{r}91 \pm 6 \\
107 \pm 6\end{array}$ \\
\hline
\end{tabular}

significant differences in herbage mass, however, between the early and late grazing periods for treatments within years $(\mathrm{P}$ $<0.01)$ and between years $(\mathrm{P}<0.01)$. Averages for the early (June) and late (July) summer grazing periods were $57 \pm$ 4 and $64 \pm 3 \mathrm{~kg} 100 \mathrm{~kg} \mathrm{steer}^{-1}$, respectively. There were significant year effects $(\mathrm{P}<$ 0.01 ) for both the June and July periods; treatment effect was significant $(\mathrm{P}<0.05)$ only for the June grazing period. The treatment means for the June period were $48 \pm 7,59 \pm 11,51 \pm 25$, and $71 \pm 38 \mathrm{~kg}$ $100 \mathrm{~kg} \mathrm{steer}^{-1}$ for the $0,170,340$, and 510 $\mathrm{kg}$ total $\mathrm{N} \mathrm{ha}^{-1}$ applied, respectively. Although, there were no significant differences in herbage mass steer ${ }^{-1}$ between treatments within a grazing period, care is still needed in interpretation of the impacts on steer weight gains.

Forage crude protein concentration was considerably higher $(\mathrm{P}<0.05)$ on 7 June 1993, compared to 1994 and 1995, in paddocks that had received higher $\mathrm{N}$ rates in the preceding 5 years (Table 5). In contrast, on 7 June 1994 and on 19 June 1995 crude protein concentrations were relatively low and similar in all treatments. This may have resulted from sampling all herbage material above a $7 \mathrm{~cm}$ height rather than selectively grazed material. Crude protein was low in 1993 and 1994 on all treatments at the end of seasonal grazing. In contrast, crude protein was relatively high at the end of seasonal grazing in 1995 . We believe this is a reflection of increased soil $\mathrm{N}$ mineralization following favorable March through July 1995 precipitation (Table 1). When these pastures were fertilized during the previous 5 years, mid-summer crude protein levels averaged $5.3,6.3,7.2$, and 8.8 percent for the 0,34 , 68 , and $102 \mathrm{~kg} \mathrm{~N} \mathrm{ha}^{-1}$ treatments, respectively (Berg and Sims 1995). Thus, forage crude protein level is an early sign that $\mathrm{N}$ is limiting plant production.

In vitro dry matter digestibility (IVDMD) was higher $(\mathrm{P}<0.01)$ in June
1993 and 1994 on treatments that had received the higher $\mathrm{N}$ rates (Table 5). By the time steers were removed in mid July 1993 and 1994, IVDMD was lower (P < 0.05 ) on treatments that had received the higher $\mathrm{N}$ rates. This lower IVDMD was a reflection of a higher proportion of stems and mature seed heads in paddocks that had received the higher $\mathrm{N}$ rates. In contrast, few Old World bluestem plants produced seedheads in the $0 \mathrm{~N}$ treatment. We have observed a similar absence of Old World bluestem heading in 5 to 10 year old Old World bluestem Conservation Reserve Program (CRP) plantings on Ndeficient farmland. During the years of fertilization, IVDMD in early summer averaged 70 to 72 percent and 59 to 61 percent during the mid-July period (Berg and Sims 1995).

\section{Steer gains}

Steer average daily gain (ADG) in 1993 was greater $(\mathrm{P}<0.01)$ on the higher $\mathrm{N}$ treatments (Table 6), probably a reflection of higher crude protein concentration in forage (Table 5). Conversely, steer ADG in 1994 was relatively low on all treatments, again a reflection of low crude protein concentrations in forage. Steer ADG during 1995 averaged $0.89 \mathrm{~kg}$ steer $^{-1}$ day $^{-}$ 1 , apparently a reflection of higher forage protein concentrations later in the grazing season (Table 5).

Weight gains of steers during 1993-1995 increased linearly with increasing $\mathrm{N}$ rates applied during the preceding 5 years (Fig. 2). Over the 3 years, steer weight gain averaged $0.63 \mathrm{~kg}$ per $\mathrm{kg}$ $\mathrm{N}$ applied during the preceding 5 years. The value can also be calculated by averaging residual $\mathrm{N}$-use efficiency over 3 years for each $\mathrm{N}$ application rate from values of $0.59 \pm 0.29$ (se) $\mathrm{kg}$ steer weight gain per total $\mathrm{kg} \mathrm{N}$ applied for the $170 \mathrm{~kg}$ $\mathrm{N}$ application, $0.68 \pm 0.06 \mathrm{~kg}$ gain per $\mathrm{kg}$ $\mathrm{N}$ for the $340 \mathrm{~kg} \mathrm{~N}$ application, and $0.63 \pm$ $0.06 \mathrm{~kg}$ gain per $\mathrm{kg} \mathrm{N}$ for the $510 \mathrm{~kg} \mathrm{~N}$ application. Total steer weight gain averaged over the 3 residual grazing years was $185 \mathrm{~kg} \mathrm{ha}^{-1}$ for the $0 \mathrm{~N}$ application, $285 \mathrm{~kg}$ $\mathrm{ha}^{-1}$ for the $170 \mathrm{~kg} \mathrm{~N} \mathrm{ha}^{-1}$ application, 416

Table 5. Crude protein and in vitro dry matter digestibility of Old World bluestems at the beginning and end of seasonal grazing of paddocks fertilized annually for the total $\mathrm{N}$ applied $\left(\mathrm{kg} \mathrm{N} \mathrm{ha}^{-1}\right)$ during the preceding 5 years at the Southern Plains Experimental Range, Ft. Supply, Okla.

\begin{tabular}{lccccc}
\hline \hline & \multicolumn{5}{c}{ Total N applied $\left(\mathrm{kg} \mathrm{N} \mathrm{h}^{-1}\right)$} \\
\cline { 2 - 6 } Forage component & Date & 0 & 170 & 340 & 510 \\
\hline Crude protein & 7 June 1993 & $8.7^{\mathrm{c}}$ & $9.6^{\mathrm{c}}$ & $10.9^{\mathrm{b}}$ & $12.1^{\mathrm{a}}$ \\
& 15 July 1993 & $5.0^{\mathrm{a}}$ & $4.8^{\mathrm{a}}$ & $4.6^{\mathrm{a}}$ & $5.2^{\mathrm{a}}$ \\
& 7 June 1994 & $7.3^{\mathrm{a}}$ & $7.1^{\mathrm{a}}$ & $7.6^{\mathrm{a}}$ & $7.6^{\mathrm{a}}$ \\
& 14 July 1994 & $6.1^{\mathrm{a}}$ & $5.7^{\mathrm{a}}$ & $4.8^{\mathrm{b}}$ & $4.7^{\mathrm{b}}$ \\
& 19 June 1995 & $7.6^{\mathrm{a}}$ & $7.8^{\mathrm{a}}$ & $7.6^{\mathrm{a}}$ & $7.7^{\mathrm{a}}$ \\
1 Aug. 1995 & $6.6^{\mathrm{b}}$ & $7.1^{\mathrm{b}}$ & $7.9^{\mathrm{a}}$ & $6.8^{\mathrm{b}}$ \\
In vitro dry matter digestibility & & & & \\
& 7 June 1993 & $65.7^{\mathrm{c}}$ & $67.0^{\mathrm{bc}}$ & $68.4^{\mathrm{ab}}$ & $69.0^{\mathrm{a}}$ \\
& 15 July 1993 & $56.6^{\mathrm{a}}$ & $54.2^{\mathrm{a}}$ & $52.8^{\mathrm{b}}$ & $51.1^{\mathrm{c}}$ \\
7 June 1994 & $62.1^{\mathrm{b}}$ & $63.5^{\mathrm{a}}$ & $64.2^{\mathrm{a}}$ & $64.0^{\mathrm{a}}$ \\
& 14 July 1994 & $57.5^{\mathrm{a}}$ & $57.3 \mathrm{a}$ & $52.9^{\mathrm{b}}$ & $51.3^{\mathrm{b}}$ \\
19 June 1995 & $61.0^{\mathrm{a}}$ & $62.1^{\mathrm{a}}$ & $62.7^{\mathrm{a}}$ & $60.1^{\mathrm{a}}$ \\
1 Aug. 1995 & $56.6^{\mathrm{a}}$ & $57.4^{\mathrm{a}}$ & $54.3^{\mathrm{a}}$ & $52.9^{\mathrm{a}}$ \\
\hline
\end{tabular}

${ }^{1}$ Values within a date followed by a common superscript are not significantly different $(\mathrm{P}>0.05)$. 


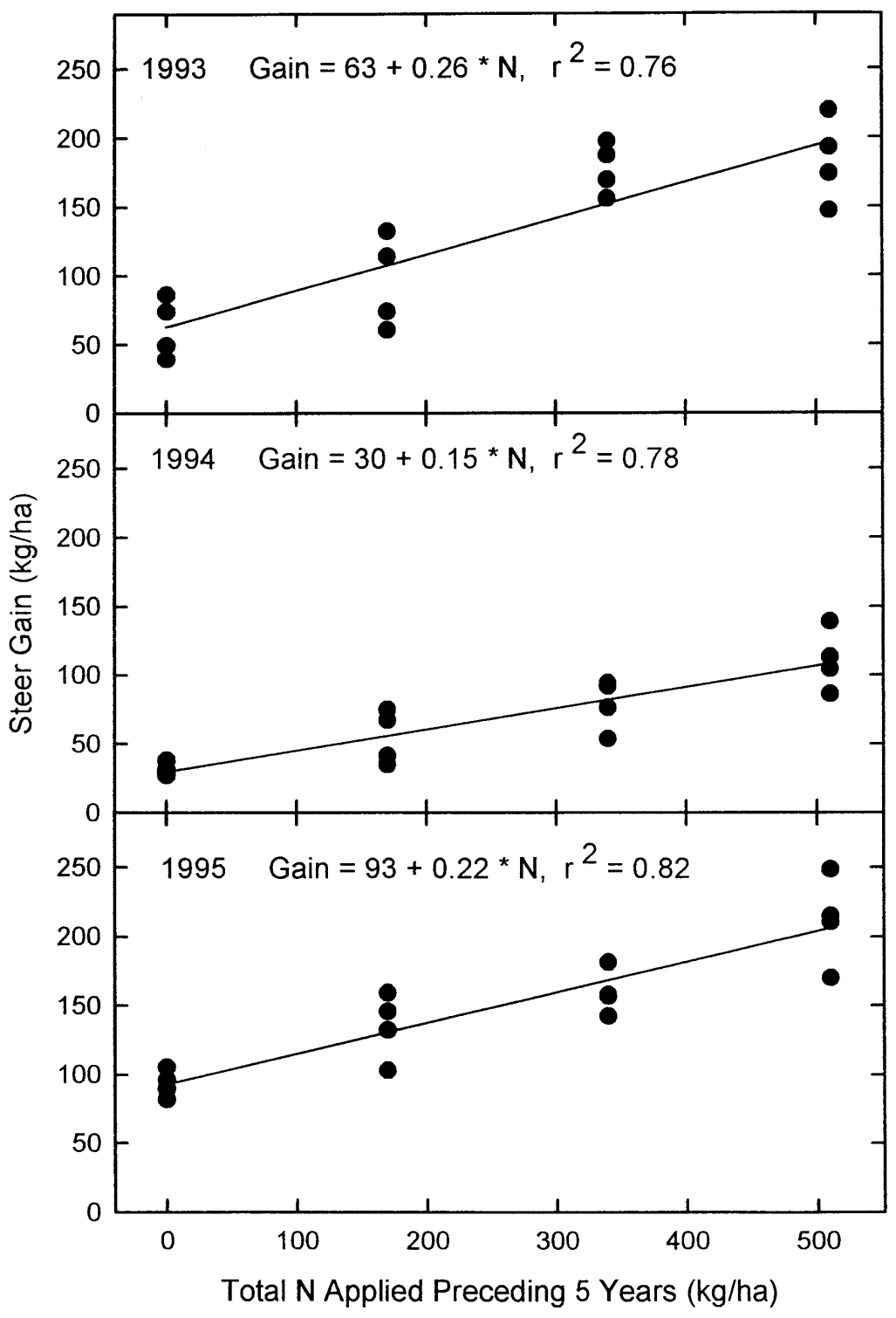

Fig. 2. Steer weight gain over 3 years as related to the total amount of $N$ applied the preceding 5 years at the Southern Plains Experimental Range, Ft. Supply, Okla.

$\mathrm{kg} \mathrm{ha}^{-1}$ for the $340 \mathrm{~kg} \mathrm{~N} \mathrm{ha}^{-1}$ application, and $505 \mathrm{~kg} \mathrm{ha}^{-1}$ for the $510 \mathrm{~kg} \mathrm{~N} \mathrm{ha}^{-1}$ application. We speculate that the residual $\mathrm{N}$ effect will be present, but diminish, over the next several years.

The residual $\mathrm{N}$-use efficiency averaging $0.63 \mathrm{~kg}$ steer weight gain per $\mathrm{kg} \mathrm{N}$ applied the preceding 5 years was additive to the fertilizer N-use efficiency previously reported (Berg and Sims 1995). A rigorous summation of fertilizer N-use efficiency during the years $\mathrm{N}$ was applied plus the residual effect was not appropriate since the study was $\mathrm{N}$ fertilized for 5 years and only grazed for 4 of these years. However, at the $34 \mathrm{~kg} \mathrm{~N}^{-1} \mathrm{yr}^{-1}$ rate, $\mathrm{N}$-use efficiency averaged $3.3 \mathrm{~kg}$ steer weight gain per $\mathrm{kg} \mathrm{N}$ applied over 4 years the pad- docks were $\mathrm{N}$ fertilized and grazed (Berg and Sims 1995) and the residual $\mathrm{N}$ effect reported here was an additional $0.59 \mathrm{~kg}$ steer weight gain per $\mathrm{kg} \mathrm{N}$ applied. Thus, the summation suggests a $\mathrm{N}$-use efficiency of about $3.9 \mathrm{~kg}$ steer weight gain per $\mathrm{kg} \mathrm{N}$ applied for the most efficient $\mathrm{N}$ application rate of $34 \mathrm{~kg} \mathrm{~N} \mathrm{ha}^{-1} \mathrm{yr}^{-1}$.

\section{Conclusions and management implications}

Annual $\mathrm{N}$ flux in rangeland is small in relation to the total $\mathrm{N}$ in soil, vegetation, and litter (Berg et al. 1997). The major $\mathrm{N}$ inputs in rangeland ecosystems are believed to be from atmospheric deposition and protein supplements fed to cattle. Primary outputs are ammonia volatilized from plant and animal wastes and livestock products sold (Woodmansee 1978, Lauenroth and Milchunas 1991). On native sandhills rangeland, 50 years of moderate grazing by cattle had no measurable effect on $\mathrm{C}$ and $\mathrm{N}$ concentrations in the surface $5 \mathrm{~cm}$ of the sandy soil or total $\mathrm{N}$ uptake by plants as compared with nongrazed areas (Berg et al. 1997). Fluxes of $\mathrm{N}$ in improved pastures would differ from those in rangeland in the amounts of $\mathrm{N}$ fertilizer applied and in the magnitude and distribution of livestock wastes distributed, protein supplements used, and products sold. An increase in total $\mathrm{N}$ averaging 5 to $8 \mathrm{~kg} \mathrm{ha}^{-1} \mathrm{yr}^{-1}$ over a 20 to 22 year period was found in $\mathrm{N}$-fertilized pastures as compared to adjacent unfertilized pastures in western Oklahoma (Berg 1988).

Nitrogen fertilization can result in soil acidification. Soil pH in the surface $5 \mathrm{~cm}$ was reduced from 6.7 to 5.3 by 20 years of $\mathrm{N}$ fertilization of improved pastures on loamy sand soils in Oklahoma (Berg 1986). In Kansas, 20 years of $67 \mathrm{~kg} \mathrm{~N}$ fertilization $\mathrm{ha}^{-1} \mathrm{yr}^{-1}$ decreased the surface $\mathrm{pH}$ of a silt loam soil under grass from 5.9 to 5.1 (Owensby et al. 1969). Generally, rangeland and grassland soils are not tillable and mixing lime to correct acidification may be difficult (Owensby and Launchbaugh 1971). Acidification of dryland grain-growing soils is an emerging problem in western North America (Mahler and Harder 1984, McCoy and Webster 1977, Westerman 1981). Plant species and selections within species vary in their sensitivity to acid soils. Foy (1984) found tall warm-season grasses were tolerant to $\mathrm{pH}$ of 4.5 to 5.0 while many legumes may be sensitive to acid soil at soil $\mathrm{pH}$ of 5.5 to 6.0 .

This study indicated that substantial residual $\mathrm{N}$ effects can be expected in forage and beef production for several years after 5 years of $\mathrm{N}$ application to Old World bluestem pastures established on marginal farmland in the Southern Plains. The 3-year residual $\mathrm{N}$ effect resulted in steer weight gain of about $0.6 \mathrm{~kg}$ per $\mathrm{kg} \mathrm{N}$ applied the preceding 5 years. At a custom grazing rate of about $\$ 0.55 \mathrm{~kg}^{-1}$ stocker weight gain, this represents an additional return of about $\$ 0.32$ per $\mathrm{kg}$ of $\mathrm{N}$ applied. Economic returns appeared to favor the 34 $\mathrm{kg} \mathrm{ha}^{-1} \mathrm{yr}^{-1}$ pasture fertilization rate. At a cost of $\$ 0.88 \mathrm{~kg}^{-1} \mathrm{~N}$ applied, the return was $\$ 1.80$ in steer weight gain (at the custom grazing rate) the year of application plus a potential $\$ 0.30$ in steer weight gain from the residual $\mathrm{N}$ effect. At higher $\mathrm{N}$ rates the return per unit of $\mathrm{N}$ applied is lower. 
Table 6. Average daily steer weight gains $\left(\mathrm{kg} \mathrm{steer}^{-1} \mathrm{day}^{-1}\right)$ and preliminary economic analysis of residual $\mathrm{N}$ effects on steer weight gains $\left(\mathrm{kg} \mathrm{steer}^{-1} \mathrm{day}^{-1}\right.$ and $\left.\mathrm{kg} \mathrm{ha}^{-1}\right)$ over 3 summer grazing periods on Old World bluestem paddocks fertlized annually at 4 rates of $\mathrm{N}$ applied $\left(\mathrm{kg} \mathrm{N} \mathrm{ha}^{-1}\right)$ during the preceding 5 years at the Southern Plains Experimental Range, Ft. Supply, Okla.

\begin{tabular}{|c|c|c|c|c|}
\hline \multirow{3}{*}{$\begin{array}{l}\text { Annual } \\
\text { Total 5-year }\end{array}$} & \multicolumn{4}{|c|}{$\mathrm{N}$ fertilization rate $\left(\mathrm{kg} \mathrm{N} \mathrm{kg}^{-1}\right)$} \\
\hline & 0 & 34 & 68 & 102 \\
\hline & 0 & 170 & 340 & 510 \\
\hline \multicolumn{5}{|c|}{ Average daily steer weight gains $\left(\mathrm{kg} \mathrm{steer}^{-1}\right.$ day $\left.^{-1}\right)$} \\
\hline 7 June-15 July 1993 & $0.67^{\mathrm{bl}}$ & $0.80^{\mathrm{b}}$ & $1.08^{\mathrm{a}}$ & $1.09^{\mathrm{a}}$ \\
\hline 7 June-14 July 1994 & $0.38^{\mathrm{b}}$ & $0.45^{\mathrm{b}}$ & $0.47^{\mathrm{b}}$ & $0.65^{\mathrm{a}}$ \\
\hline 19 June-1 Aug. 1995 & $0.89^{\mathrm{a}}$ & $0.85^{\mathrm{a}}$ & $0.83^{\mathrm{a}}$ & $1.00^{\mathrm{a}}$ \\
\hline \multicolumn{5}{|l|}{ Total steer gain } \\
\hline -3-year gain $\left(\mathrm{kg} \mathrm{ha}^{-1}\right)$ & 185 & 285 & 416 & 505 \\
\hline - Total $\mathrm{N}$ cost $\left(\$ 0.66 \mathrm{~kg}^{-1} \mathrm{~N}\right)$ & 0 & $\$ 112.20$ & $\$ 224.40$ & $\$ 336.60$ \\
\hline \multicolumn{5}{|l|}{ Economic component: } \\
\hline - $\mathrm{N}$-use $\left(\mathrm{kg}\right.$ gain $\left.\mathrm{kg} \mathrm{N}^{-1}\right)$ & Baseline & 0.59 & 0.68 & 0.63 \\
\hline - Additional gain $\left(\mathrm{kg} \mathrm{ha}^{-1}\right)$ & - & 100 & 231 & 320 \\
\hline \multicolumn{5}{|c|}{ Comparison based on steer ownership } \\
\hline - Value of gain $\left(\$ 1.10 \mathrm{~kg}^{-1}\right)$ & - & $\$ 110.00$ & $\$ 254.10$ & $\$ 352.00$ \\
\hline - Total sales $\left(\$ 1.10 \mathrm{~kg}^{-1}\right)$ & $\$ 203.50$ & $\$ 313.50$ & $\$ 457.60$ & $\$ 555.50$ \\
\hline - Sales less N costs & $\$ 203.50$ & $\$ 201.30$ & $\$ 233.20$ & $\$ 218.90$ \\
\hline \multicolumn{5}{|c|}{ Comparison based on custom grazing rates: } \\
\hline - Custom rates $\left(\$ 0.55 \mathrm{~kg}^{-1}\right)$ & $\$ 101.75$ & $\$ 156.75$ & $\$ 228.80$ & $\$ 277.75$ \\
\hline - Return (Custom rate-N) & $\$ 101.75$ & $\$ 44.55$ & $\$ 4.40$ & $-\$ 58.85$ \\
\hline
\end{tabular}

${ }^{1}$ Steer weight gains within a year followed by a common superscript are not significantly different $(\mathrm{P}>0.05)$.

Preliminary economic returns to the resources used and to management have been estimated for both yearling stocker ownership and custom grazing rates (Table 6). Assuming all other costs are proportional, the $68 \mathrm{~kg} \mathrm{~N}$ ha rate yielded $\$ 233.20$ per ha for the 3 years of grazing pastures that were fertilized during the previous 5 years. The returns of all 4 fertilizer rates ranged between $\$ 203$ and $\$ 233$. Using a custom grazing rate of $\$ 0.55 \mathrm{~kg}^{-1}$, returns to fertilizer applied ranged from a low of $-\$ 58.85$ to a high of $\$ 101.75$ for the 3 year period. In this case, the unfertilized control had the highest return, followed by the 34 and $68 \mathrm{~kg} \mathrm{~N}^{-1}$ at $\$ 44.55$ and $\$ 4.40$, respectively. The 102 $\mathrm{kg} \mathrm{N} \mathrm{ha}^{-1}$ rate lost an estimated $\$ 58.85$ for the 3 years that residual $\mathrm{N}$ effects were measured. Additional economic analyses are needed to evaluate net returns for the 5 years of $\mathrm{N}$ fertilization plus the 3 years of residual $\mathrm{N}$ effects reported here.

\section{References}

Berg, W. A. 1986. Effect of 20 years of low N rate pasture fertilization on soil acidity. $\mathrm{J}$. Range Manage. 39:122-124.

Berg, W. A. 1988. Soil nitrogen accumulation in fertilized pastures of the Southern Plains. J. Range Manage. 41:22-25.

Berg, W. A. 1994. Sand sagebrush-mixed prairie. pp. 99. In: T. N. Shiflet (ed.) Rangeland cover types of the United States. SRM, Denver, Colo.
Berg, W. A. and P. L. Sims. 1995. Nitrogen fertilizer use efficiency in steer gain on Old World bluestem. J. Range Manage. 48:465-469.

Berg, W. A., J. A. Bradford, and P. L. Sims. 1997. Long-term soil nitrogen and vegetation change on sandhill rangeland. J. Range Manage. 50:482-486.

Bock, B. R. and G. W. Hergert. 1991. Fertilizer nitrogen management. p. 139-164. In R. F. Follett, D. R. Keeney, and R. M. Cruse (eds.). Managing nitrogen for ground water quality and farm profitability. Soil Sci. Soc. Amer. Madison, Wisc.

Bremner, J. M. and G. A. Breitenbeck. 1983. A simple method for determination of ammonium in semimicro-kjeldahl analysis of soils and plant materials using a block digester. Commun. Soil Sci. Plant Anal. 14:905-913.

Dahl, B. E. and P. F. Cotter. 1984. Management of weeping lovegrass in west Texas. Management Note 5. Dept. Range and Wildlife Mgt. Texas Tech Univer., Lubbock, Tex.

Dahnke, W. C. and G. V. Johnson. 1990. Testing soils for available nitrogen. p. 127139. In: R. L. Westerman (ed.) Soil testing and plant analysis. Soil Sci. Soc. Amer. Inc. Madison, Wis.

Foy, C. D. 1984. Physiological effects of hydrogen, aluminum, and manganese toxicities in acid soil. p. 57-97. In: F. Adams (ed) Soil Acidity and Liming, 2nd ed. Amer. Soc. Agron. Madison, Wisc.

Gelderman, R. H. and P. E. Fixen. 1988. Recommended nitrate-N tests. p. 10-12. In: Recommended Chemical Soil Test Procedures. North Dakota Agric. Exp. Sta. Bull 499. North Dakota Agric. Exp. Sta. Fargo, N.D.

Haas, H. J., C. E. Evans, and E. F. Miles. 1957. Nitrogen and carbon changes in Great
Plains soils as influenced by cropping and soil treatments. USDA Tech. Bull. 1164. U.S. Printing Office, Washington, D.C.

Keeny, D.R. and D.W. Nelson. 1982. Nitrogen-Inorganic forms. p. 643-698. In A. L. Page (ed.) Methods of soil analysis, Part 2. Amer. Soc. Agron. Madison, Wisc.

Lauenroth, W.K. and D.G. Milchunas. 1991. Short-grass steppe. p. 183-226. In: R. T.Coupland (ed.) Natural Grasslands: Introduction and Western Hemisphere, Ecosystems of the World. Vol. 8A, Elsevier, New York.

Mahler, R.H., and R.W. Harder. 1984. The influence of tillage methods, cropping sequence, and $\mathrm{N}$ rates on the acidification of a northern Idaho soil. Soil Sci.137:52-60.

McCoy, D.A., and G.R. Webster. 1977. Acidification of a luvisolic soil caused by low rate, long-term applications of fertilizers and its effects on growth of alfalfa. Can. J. Soil Sci. 57:119-127.

Nelson, D.W. and L.E. Sommers. 1982. Total carbon, organic carbon, and organic matter, p. 539-579. In: A. L. Page (ed.) Methods of soil analysis, Part 2. Amer. Soc. Agron. Madison, Wisc.

Owensby, C. E., and J. L. Launchbaugh. 1971. Acidifying nitrogen compounds and range fertilization. J. Range Manage. 24:203-206.

Owensby, C.E., K.L. Anderson, and D. A. Whitney. 1969. Some chemical properties of a silt loam soil after 20 years' nitrogen and phosphorus fertilization of smooth bromegrass (Bromus inermis Leyss.). Soil Sci. 108:24-29.

SAS Institute. 1985. SAS user's guide: Basics. SAS Institute. Cary, N.C.

Sims, P. L. and C. L. Dewald, 1982. Old World bluestems and their forage potential for the Southern Great Plains. A review of early studies. Agr. Res. Serv. Agr. Rev. Man., South. Series, No. 28. 15 p.

Tilley, J. M. A. and R. A. Terry. 1963. A two stage technique for the in vitro digestion of forage crops. J. Brit. Grassl. Soc. 18:104111.

Westerman, R. L. 1981. Factors affecting soil acidity. Solutions 25:64-81

White, L. M., G. P. Hartman, and J. W. Bergman. 1981. In vivo digestibility, crude protein, and phosphorus content of straw of winter wheat, spring wheat, barley, and oat cultivars in eastern Montana. Agron. J. 73:117-121.

Woodmansee, R. G. 1978. Additions and losses in nitrogen in grassland ecosystems. Bioscience 28:448-453. 